
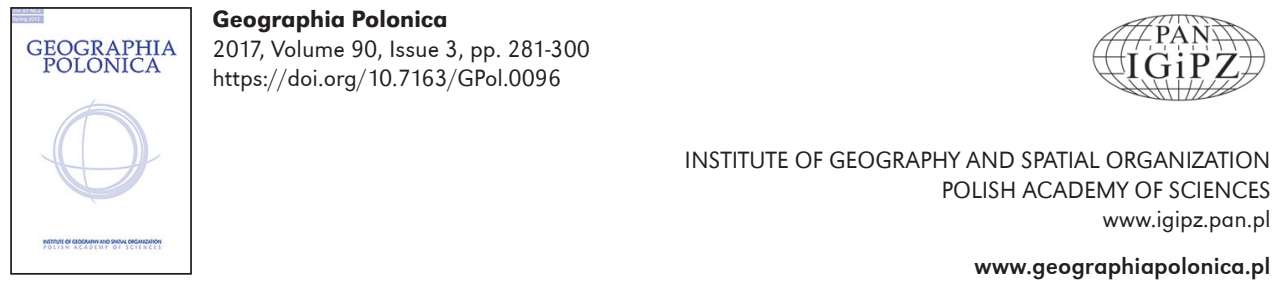

\title{
tÓDŹ METROPOLITAN AREA: DELIMITATION, PLANNING AND DEVELOPMENT
}

\section{Tadeusz Marszał}

Institute of the Built Environment and Spatial Policy, Faculty of Geographical Sciences

University of Łódź

Kopcińskiego 31, 90-142 Łódź: Poland

e-mail: marsz@uni.lodz.pl

\begin{abstract}
In the last 25 years, Łódź and the region surrounding the city have undergone significant transformations in respect of both the socio-economic structure and spatial development. In consequence of radical restructuring carried out after 1990, the traditional manufacturing branches disappeared and have been replaced by dynamically growing new types of business activity, especially in the services sector, which has enhanced the metropolitan character of Łódź and strengthened the functions belonging to 4th sector of the economy. The purpose of this article is identification of the actual extent of Łódź Metropolitan Area in terms of the functions performed and its delimitation for management purposes, as well as analysis of conditions for further development of this area in the context of metropolisation processes. Future development largely depends on making good use of the favourable location in European space, European funds, cultural heritage and social potential. A serious challenge is coordination of activities of territorial self-government units and revision of the policies of the communes so as to create a consistent conception of the development of the metropolitan area. Łódź Metropolitan Area, despite certain barriers, has a potential strong enough to become an advanced, creative node in the sphere of culture, science and innovative economy, and a major element of the European settlement system.
\end{abstract}

\section{Key words}

Łódź • metropolitan area $・$ metropolitan functions

\section{Introduction}

In contemporary world, cities, both large and small, are no longer independent elements of spatial structures - increasing interchange with the environment (made possible by development of transport systems and greater mobility of the population) leads to the emergence of urbanized space of greater extent and stronger functional ties. Large urban settlement systems, by concentrating the demographic and socio-economic potential of countries, are becoming major nodes in space organization, having increasing importance and power of influence (Castells 2002). There is a lasting tendency towards 
transformation of cities into regions, which in turn are becoming increasingly complex systems (Markowski 2005: 10-11).

In the sphere of scientific research, the changes that are taking place in cities and the space surrounding them are reflected in various research concepts and proposals for practical solutions concerning management and organization of urbanized space. The concepts most often referred to in academic publications are, among others, daily urban systems (Berry 1967) and functional urban regions (Korcelli-Olejniczak 2012: 33-37). From the perspective of organization and management of urban regions, whose core is the central city performing metropolitan functions, of key importance is the concept of metropolitan area, which emerged already in the 1930s (McKenzie 1933; Dickinson 1934). Moreover, there are voices in the literature of the subject that the division into metropolitan areas and non-metropolitan peripheral areas is the most clear and synthetic view of the spatial structure of the settlement system (Friedman \& Miller 1965: 312-320; Korcelli-Olejniczak 2012: 34). The main dimension of Polish space differentiation in the 21 st century is the dichotomy: metropolitan areas - non-metropolitan areas (Domański 2008: 135).

The interest of the Polish academic community in metropolitan issues found expression in numerous publications on this subject which appeared in the last two decades. In the case of Łódź Metropolitan Area ( $Ł M A)$, issues that receive the most attention include identification of key development problems in this area, its delimitation, functional structure and links with the environment, both in the national and international dimension, management of the area, and determinants and directions of its spatial development.

In the past few decades, the socio-economic structure and spatial development of the Łódź region have undergone significant transformations. In consequence of the restructuring that took place after 1990, the traditional manufacturing industries typical of this area for the last two centuries have disappeared and have been replaced by new, dynamically growing types of economic activity, especially in the services sector, which strengthens the metropolitan position of Łódź and the functions regarded as the 4 th sector of the economy.

Metropolitan areas, which in many countries have long been an essential element of the spatial organization, were introduced by law into Polish spatial planning practice in 2013. Although to date there are no provisions regulating such matters as the exact definition, objectives, delimitation and institutionalisation, and forms of managing metropolitan areas, a number of practical activities aimed at new organization of space surrounding Poland's largest cities have been undertaken by scholars, planners and local governments. This study presents major issues concerning the functioning of Łódź Metropolitan Area, including its delimitation and functional structure. The main goal of the article is to identify crucial opportunities and barriers in further development of the metropolitan area enabling the assessment of the growth potential of the region which over the last century depended on textile manufacturing.

\section{Delimitation and boundaries of Łódź Metropolitan Area}

Definition of the concept of metropolitan area is the starting point for undertaking delimitation of such an area. First attempts at formulating a definition (sometimes actually preceding delimitation of some areas referred to as metropolitan) can be found in Polish literature in the 1960s-1970s (e.g. Lier 1965; Klimczyk \& Mijakowski 1968; Dziewoński 1973; Gontarski 1980). This is a difficult task since there are very many terms relating to urbanized areas and large urban settlement forms (Kaczmarek \& Mikuła 2007: 10). The concept of metropolitan area has been the subject of extensive analysis, especially regarding such concepts of urbanized areas organization as city (urban) region (Berry 1967; Korcelli 1981), functional urban region (Hay \& Hall 1977; Hall \& Hay 1980; Cheshire \& Hay 1989; Potrykowska 1989), urban field (e.g. Friedman \& Miller 1965; Berry \& Gillard 1977), or urban 
agglomeration (e.g. Dziewoński 1975; Korcelli 1976; Czyż 2009).

Delimitation of the sphere of influence of large cities has also received much attention in Polish literature (Eberhardt 2002). The proposals in publications dealing with this topic differ widely depending on the research conception adopted in a given study as well as the choice of criteria and the period that they refer to (Iwanicka-Lyra 1969; Swianiewicz \& Klimska 2005; Smętkowski 2007; Smętkowski et al. 2009). A proposal concerning delimitation of metropolitan areas in Poland appeared as early as the 1970s (Gontarski 1972). The subsequent publications addressing the issue of metropolitan areas delimitation contain proposals referring to daily urban system (e.g. Tarkowski 2005) as well as the functionalstructural approach (Zborowski 2004). In recent years much attention has been devoted to delimitation of functional urban areas and their application in the practice of spatial planning (e.g. Śleszyński 2013; Rakowska 2014; Śleszyński 2014, 2015; Śleszyński \& Komornicki 2016).

Many authors who undertake analysis of daily urban systems and functional urban areas refer to traffic flows and commuting patterns (cf. e.g. Kunc et al. 2012; Mantley 2014). In this approach, functional urban region can be defined as travel-to-work area. Principally, it is an agglomeration of work places attracting the work force from the surrounding area. ${ }^{1}$ In this context differences between polycentric and monocentric urban systems are discussed and economic consequences of polycentricity, including e.g. costs of commuting, are assessed (e.g. Veneri 2010; Brezzi \& Veneri 2014).

The problems that have to be faced - especially in the case of the structural approach to the question of delimitation - are made even more complex by development of urbanized areas taking the form of urban sprawl or leapfrog development, which results in new

1 If a certain share of the labour force in a defined fringe area are out-commuters it is attached to the municipality to which the largest portion of commuters go (Antikainen 2005: 448). settlement units separated by undeveloped areas (Kaczmarek \& Mikuła 2007: 14).

Defining the concept of metropolitan area from the morphological perspective is therefore not easy, and its extent cannot be equated with the suburban zone. Identification of metropolitan areas only by means of number of inhabitants is an oversimplification, as well. ${ }^{2}$ The characteristic features of a metropolitan area understood as a large urban settlement network should include:

- extent of direct daily interaction (influence);

- metropolisation processes and accumulation of activities supplementing the metropolitan functions of the central city;

- strong internal functional ties;

- well-developed transport network.

A metropolitan area should also have a distinct management system (Markowski \& Marszał 2006a: 15). ${ }^{3}$

Besides the question of definition of a metropolitan area, an equally important issue is the choice of criteria to be used in delimiting it. The criteria that should be taken into account in determining the extent of a metropolitan area are (Markowski \& Marszał 2006a: 15-16):

- links between the metropolitan centre and the surrounding region - jointly performed functions, economic and social ties with surrounding local government units (functional criterion);

- demographic potential, population density and migration size (demographic criterion);

- level, rate of growth and types of economic activity (economic criterion);

- type of land use and housing (urban planning criterion);

- level of technical infrastructure development (technical criterion);

- commuting to work and school (area of direct attraction of the metropolitan centre);

\footnotetext{
${ }^{2}$ According to the OECD, the sole criterion for identifying a metropolitan area is number of inhabitants exceeding 500 thousand (Dijkstra \& Poelman 2012).

3 More about the definition of metropolitan area in i.a. Markowski \& Marszał (2006b); Markowski \& Marszał (2007: 18-21); Pielesiak (2007).
} 
- political will of local government entities to cooperate within the metropolitan area (management criterion);

- spatial cohesion criterion.

A metropolitan area should also fulfil the conditions ensuring spatial cohesion, i.e.:

- cover territories lying within a commuting distance;

- encompass all municipalities adjoining the metropolitan city (close neighbourhood principle);

- exclude the municipalities not adjoining the metropolis directly or through other municipalities that have the required parameters (contiguity principle);

- include the municipalities that do not fit the adopted criteria, but border only on municipalities that meet them (compactness principle).

Delimitation of a metropolitan area is a very complex and ambiguous undertaking (especially in Poland) because of multiple views on the definition of a metropolitan area as well as the purposes to be achieved by delimitation. The strength, character and range of connections between the central city and its surroundings can be considered as the main criterion for delimitation of a metropolitan area defined as territory functionally bound with the metropolis (large city fulfilling metropolitan functions) (Pielesiak 2012b: 171-172).

The question of Łódź Metropolitan Area delimitation has been discussed for more than a decade. One of the proposals was presented by Liszewski (2005), who based his analysis on four parameters: concentration of population, ${ }^{4}$ internal migrations, distribution of business entities and the recreational function. He made the assumption that metropolis represents a development phase of large settlements in the process of geographical space urbanisation, and after reaching 'maturity' (mainly functional) the city

\footnotetext{
4 The choice of this measure was guided by the observation that population concentration is closely connected with agglomeration processes, and its expansion to areas surrounding the metropolis indicates incorporation of new geographical spaces in urban centre life cycle.
}

undergoes the deconcentration process ${ }^{5}$ due to centrifugal forces, which, operating alongside the concentration processes, stimulate the expansion of the urban agglomeration, thus starting the formation of a metropolitan area, which is a manifestation of the spatial development and a new phase in the urbanization process referred to as metropolisation.

On the basis of analysis of the four criteria listed above, Liszewski (2005) drew the following conclusions:

- a period of high and growing concentration of population in Łódź was followed by a marked increase in densely populated areas around this city, with a decreasing role of Łódź in this spreading high density territory;

- three of the poviats (districts) surrounding Łódź, i.e. Łódź East, Zgierz and Pabianice poviats (districts), have experienced a relatively large inflow of Łódź citizens and can therefore be regarded as part of Łódź Metropolitan Area, while the fourth of the neighbouring poviats (districts)- Brzeziny - is in a less advanced phase of metropolisation, but this process will soon accelerate there, too;

- there is a strong coincidence between the transferring of business activity to the outer zone of the agglomeration and the intensified outmigration from Łódź;

- the recreational space for Łódź agglomeration citizens covers roughly the areas of the four neighbouring districts.

These conclusions are confirmed by other researchers engaged in the study of demographic issues and economic potential of local government entities forming Łódź Metropolitan Area (ŁMA), and social ties between them (e.g. Bartosiewicz 2012a; Ogrodowczyk 2012). In the majority of scientific studies dealing with metropolitan areas as well as for administrative and planning purposes it is assumed that $Ł M A$ is comprised of the city of Łódź and

\footnotetext{
${ }^{5}$ In the initial phase, the urbanisation process is mainly connected with forces attracting population and causing its concentration along with concentration of building development, economy and social activity in a certain area, which results in the emergence and growth of a city.
} 


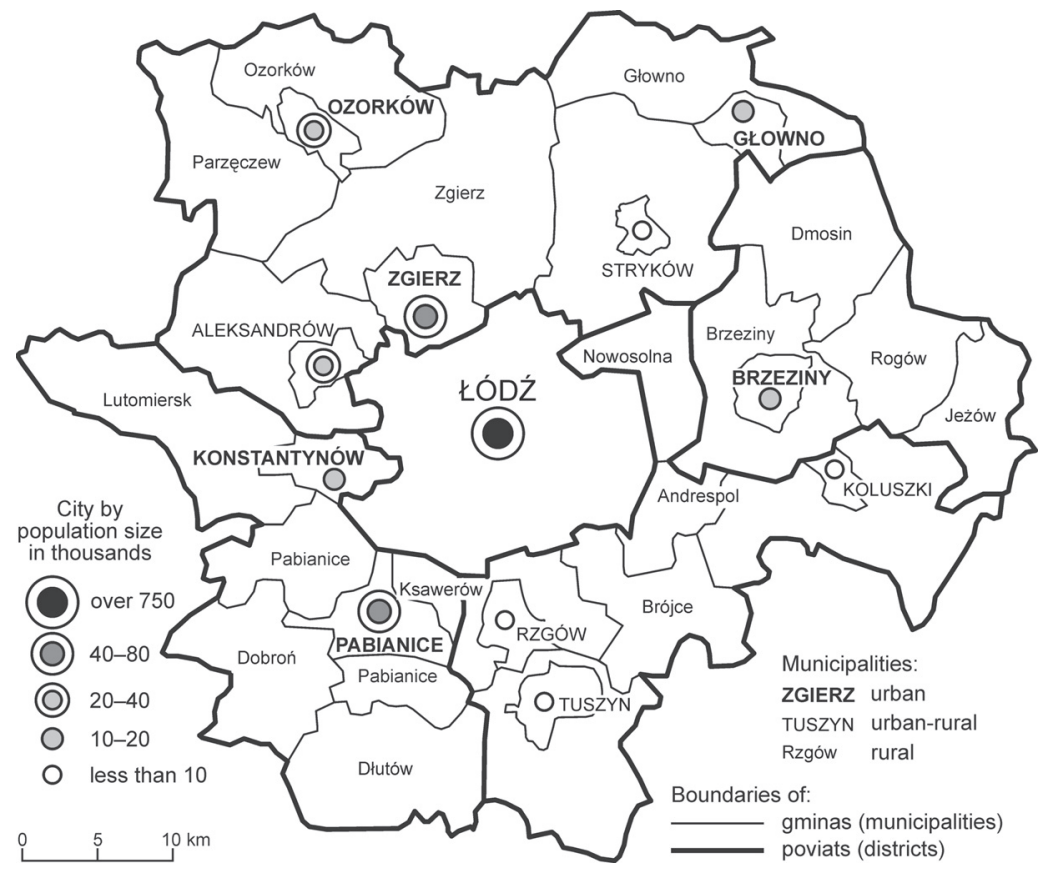

Figure 1. Administrative division of Łódź Metropolitan Area

four poviats (districts) surrounding it: Zgierz, Pabianice, Łódź East and Brzeziny poviats (districts) (cf. i.a. Wolaniuk 1997; Liszewski 2005; Marszał \& Pielesiak 2008; Feltynowski 2009; Jewtuchowicz \& Wójcik 2010; Suliborski \& Przygocki 2010). A number of works cited in this paper demonstrate that thus delimited $Ł M A$ constitutes a fairly compact and functionally linked area with good transport accessibility, where the majority of municipalities are characterized by a high level of urbanization and a dominant share of non-agricultural functions (cf. Pielesiak 2012b: 173).

Another conclusion drawn from research is that it is not possible to establish the exact boundary of $Ł M A$ so as to meet all the delimitation criteria. Analysis of the elements creating the metropolitan character of an area indicates that the boundary of ŁMA has a zonal character, is dynamic and undergoes changes. $Ł M A$, established for practical reasons for the purposes of planning and management, is characterized by spatial variation in terms of territorial cohesion. The municipalities situated in the northern and north-eastern peripheries of this area exhibit weaker functional integration due to having less developed productive and service functions as well as infrastructure elements that create cohesion (the municipalities of Głowno, Ozorków, Parzęczew, Dmosin, Jeżów and Rogów, and Dłutów in the south). ${ }^{6}$ Also in the Brzeziny District metropolisation processes are rather weak. Given that $Ł M A$ is among the smallest in Poland in terms of area, while having considerable population and economic potential, its degree of cohesion does not seem to deviate significantly from the cohesion of the remaining metropolitan areas in Poland.

The accepted extent of $Ł M A$, practically raising no controversy, ${ }^{7}$ comprises Łódź and

\footnotetext{
${ }^{6}$ See the conclusions concerning the functional diversity of municipalities, presented further in the text.

7 There are some suggestions to incorporate in $Ł M A$ further cities and municipalities that have strong ties with Łódź: Zduńska Wola, Łask and Wodzierady. There also are proposals postulating inclusion of larger cities like Sieradz, Piotrków Trybunalski and Łęczyca
} 


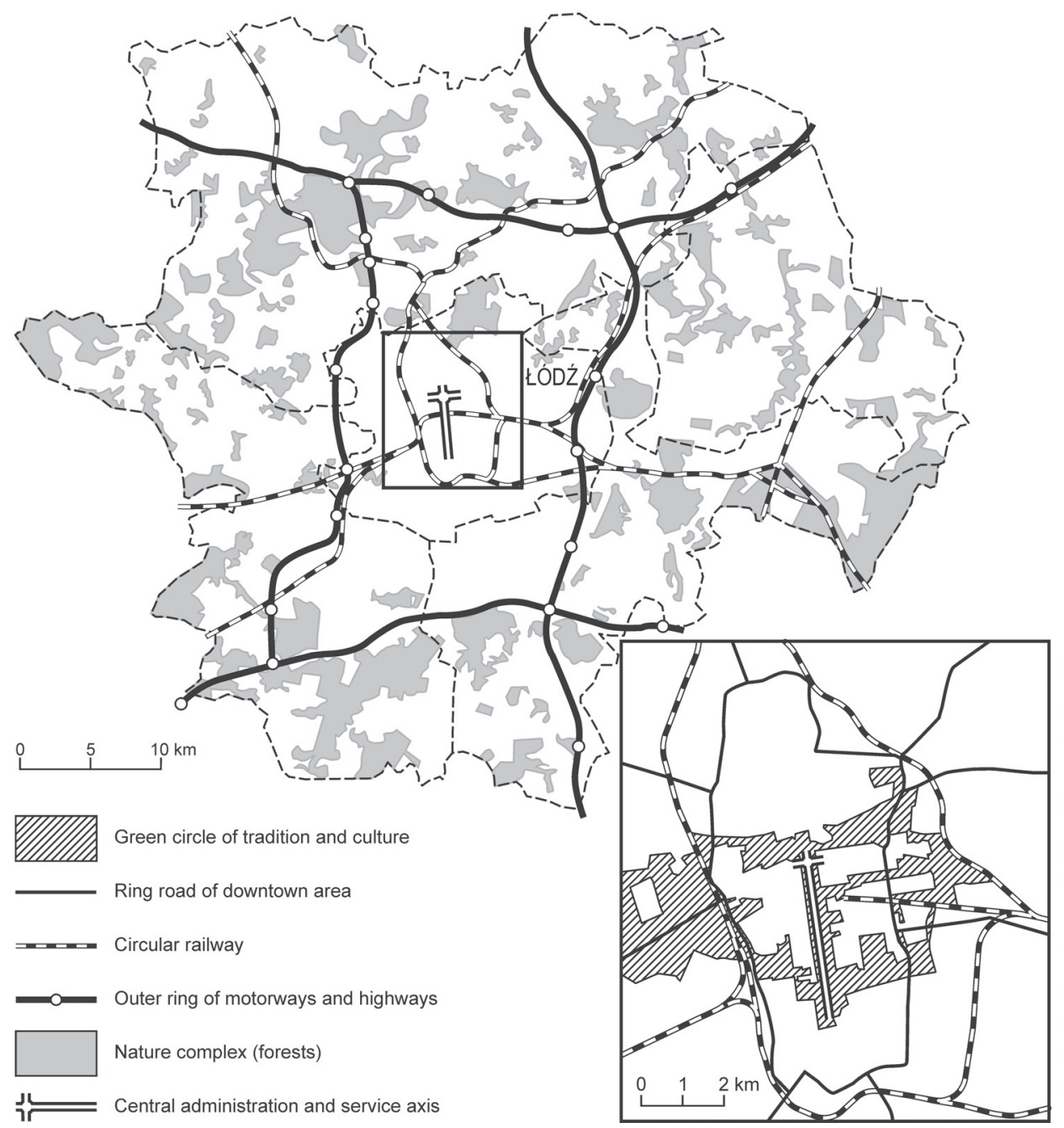

Figure 2. The concentric structure of Łódź Metropolitan Area.

Source: based on Bald 2005: 161.

four districts encompassing the metropolitan centre, which are further subdivided into 27 municipalities (see Fig. 1). The metropolitan area extends over 2.5 thousand sq. kilometres (13.7\% of Łódź voivodeship) and has a population of 1,117 thousand (2010), which gives the average population density of 447 persons/sq. kilometre (the voivodeship average is 139 persons/sq. kilometre). The proportion of urban population is $87 \%, 64 \%$ being the average for the voivodeship.
The spatial structure of $Ł M A$ has a concentric character - considering the planned creation of the lacking elements, the beltway system forms successive rings around the centre of the metropolis (Fig.2) (Bald 2005: 160-162):

- a ring comprising the central circle of tradition and culture (the city's green areas forming one system of environmental value and containing basic elements of the material identity of the city); 
- a ring formed by the beltway of the broad downtown area (Wojska Polskiego Street, the planned Konstytucyjna Street, Trasa Górna and Al. Włókniarzy);

- a ring formed by a circular railway plus interlinks (which will enable the utilisation of the infrastructure for traffic within the city and metropolitan area);

- a ring formed by roads of supra-regional importance, including sections of A1 and A2 motorways and S8 and S14 highways;

- an outer ring of forests fulfilling the recreational function.

\section{Functions of $Ł M A$}

The main distinguishing feature of metropolitan areas are functions which have a specific character and determine the area's status in socio-economic space (exogenous functions of at least supra-regional range and significance). However, due to different approaches to defining a function and the concept of 'metropolitan', there are only relative and subjective possibilities of identifying the metropolitan functions. Many scientific studies have been devoted to various aspects of the functional development of Łódź agglomeration (cf. eg. Liszewski 1999; Marszał 2004). The functions regarded as being of primary importance for the metropolitan character of Łódź and the encompassing area include (Marszał 2005a: 52-53):

- science and higher education (17 higher education establishments, 92 thousand students, about 5 thousand academic teachers, nearly 40 research institutes); 8

- cultural institutions (numerous theatres and festivals, including eight repertory theatres, an opera house, museums, art schools, etc.);

- business services (legal, financial, information), public administration and regional level justice authorities);

- numerous hotels;

- financial and insurance institutions (numerous bank branches or divisions);

\footnotetext{
${ }^{8}$ For more on academic functions of Łódź see Li-
} szewski et al. (2008).
- highly specialized health service (over 20 hospitals, including research hospitals); - production based on advanced technologies (technology parks, 24 R\&D units or branches of non-local establishments);

- supra-regional commercial and service function (Rzgów-Tuszyn-Głuchów complex, large centres of commerce and entertainment: Manufactura and Port-Łódź);

- transport function (supra-regional transport hub - intersection of A1 and A2 motorways, S8 and S14 highways, reconstructed Łódź railway junction and airport) and the related logistics function.

What is important in the process of metropolitan functions development is not only the competitive position of the central city but also of the entire metropolitan area, consisting of different local government units varying in terms of functions, social structure and spatial development. The functional diversity of ŁAM (Łódź and four neighbouring districts) was the subject of research investigating core economic functions and the housing function in each of the constituent municipalities (administrative districts in the case of Łódź) (Marszał 2005a,b). The research has confirmed the high diversification of $Ł A M$ only Łódź, the neighbouring cities and the municipalities adjoining Łódź exhibit strong functional integration and presence of typically urban functions, while the outlying communes are characterized by a lower degree of production and service functions development, lower population density and dominance of the agricultural function. Among the gminas (municipalities) with rural status or partly rural status, Ksawerów, Andrespol, Pabianice, Aleksandrów Łódzki and Rzgów have well-developed production and services. A tendency to deconcentration of the housing function and inflow of population from Łódź is particularly visible in Andrespol, Konstantynów, Ksawerów, Zgierz and Aleksandrów, all of which are units adjoining Łódź. The gminas (municipalities) with the least developed metropolitan functions are those situated in the northern and north-eastern part of $Ł A M$, which is confirmed by research on the housing 
Table 1. The functional structure of Łódź Metropolitan Area

\begin{tabular}{|c|c|c|c|c|c|}
\hline $\begin{array}{c}\text { Gmina } \\
\text { (municipality) }\end{array}$ & $\begin{array}{l}\text { Agricultural } \\
\text { function }\end{array}$ & $\begin{array}{l}\text { Non-agricultural } \\
\text { production }\end{array}$ & $\begin{array}{l}\text { 3rd sector } \\
\text { services }\end{array}$ & $\begin{array}{l}\text { 4th sector } \\
\text { services }\end{array}$ & Housing \\
\hline Łódź & - & ++ & ++ & +++ & +++ \\
\hline \multicolumn{6}{|l|}{ Brzeziny poviat } \\
\hline - Brzeziny & - & +++ & ++ & ++ & + \\
\hline - Brzeziny & ++ & ++ & ++ & - & - \\
\hline - Dmosin & +++ & + & ++ & - & - \\
\hline - Jeżów & ++ & + & + & - & - \\
\hline - Rogów & + & + & + & - & - \\
\hline \multicolumn{6}{|l|}{ Łódź East poviat } \\
\hline - Koluszki & - & ++ & ++ & + & ++ \\
\hline - Tuszyn & - & +++ & +++ & + & + \\
\hline - Andrespol & - & +++ & ++ & + & + \\
\hline - Brójce & ++ & ++ & + & + & - \\
\hline - Koluszki & - & + & + & - & - \\
\hline - Nowosolna & - & ++ & ++ & - & - \\
\hline - Rzgów & + & +++ & +++ & + & + \\
\hline - Tuszyn & + & + & ++ & - & - \\
\hline \multicolumn{6}{|l|}{ Pabianice poviat } \\
\hline - Konstantynów & - & ++ & ++ & + & + \\
\hline - Pabianice & - & +++ & ++ & ++ & ++ \\
\hline - Dłutów & ++ & ++ & + & - & - \\
\hline - Dobroń & - & ++ & ++ & - & - \\
\hline - Ksawerów & - & +++ & +++ & ++ & + \\
\hline - Lutomiersk & + & ++ & + & - & - \\
\hline - Pabianice & + & +++ & ++ & - & - \\
\hline \multicolumn{6}{|l|}{ Zgierz poviat } \\
\hline - Aleksandrów Ł. & - & +++ & ++ & + & ++ \\
\hline - Głowno & - & +++ & ++ & + & + \\
\hline - Ozorków & - & + & ++ & + & ++ \\
\hline - Stryków & - & ++ & ++ & + & + \\
\hline - Zgierz & - & ++ & ++ & ++ & ++ \\
\hline - Aleksandrów Ł. & + & +++ & ++ & + & - \\
\hline - Głowno & +++ & - & - & - & - \\
\hline - Ozorków & +++ & - & + & - & - \\
\hline - Parzęczew & ++ & + & - & - & - \\
\hline - Stryków & ++ & ++ & + & - & - \\
\hline - Zgierz & - & ++ & ++ & + & - \\
\hline
\end{tabular}

- poorly developed function or its absence......... $+1+$ well developed function

(Degree of function development is based on: in agriculture - \% of agricultural population; in non-agricultural sectors - number of businesses/1thousand residents; in housing - number of flats/sq. kilometre)

Source: based on Marszał 2005a,b. 
physiognomy - farmsteads, which are typical of agricultural areas, dominate in those peripheries. Metropolitan functions sensu stricto are concentrated in the central part of Łódź, while around the central city there is no fully developed (in functional terms) metropolitan zone, understood as an area with a complementary functional structure regarding higher order services (university campuses, technology parks, commerce and entertainment centres).

\section{Łódź Metropolitan Area development planning}

In 2004, the president of Łódź commissioned preparation of a study Obszar Metropolitalny Łodzi - wyzwania i problemy (Łódź Metropolitan Area - challenges and problems) (Bald \& Markowski 2005: 7), aimed at determining conditions which need to be fulfilled to enable city authorities to undertake effective development of metropolitan space. This study was intended to spread the knowledge of the problems of the emerging ŁMA and to raise discussion on this subject. It consisted of a number of sections relating to management, delimitation, functional structure and determinants of future directions of this area's development.

During the last decade this topic was addressed by a number of other planning studies, such as Plan zagospodarowania województwa tódzkiego (Development Plan for Łódź Voivodship) of 2002 and its updated version of 2010 (Plan ... 2010), Studium uwarunkowań i kierunków zagospodarowania przestrzennego Łodzi (Study of determinants and directions of spatial development of Łódź) of 2010, or Strategia rozwoju województwa łódzkiego (Strategy of Łódź Voivodeship development) of 2013.

In 2013, Studium rozwoju Łódzkiego Obszaru Metropolitalnego (Studium ... 2013) (Study of the development of Łódź Metropolitan Area) was elaborated, with the aim of "identification of major development potentials of this area and indicating actions which would accelerate the process of its metropolisation.
The proposed measures should utilise and strengthen the identified potentials, while also eliminating the development barriers". Major challenges facing ŁMA, as recognised in the study, are:

- development of metropolitan functions based on innovative economy and the creative sector;

- revitalisation of technically, socially and economically degraded parts of the cities;

- integration of the public transport system to ensure the spatial cohesion of this area.

This study does not have an obligatory character - it only contains suggestions concerning key actions conditioning the formation of the metropolitan area and its development in the long term (2020+). It is an open-type document, intended as starting material for elaboration of $Ł A M$ development strategy.

In 2013, Łódź received a subsidy for elaboration of Łódź Metropolitan Area Development Strategy, which enabled the signing of an agreement between all local government units participating in this project, whose completion was planned for March 2015. ${ }^{9}$ Its aims include promoting closer cooperation between local government entities making up the metropolitan area and creating conditions for more effective spending of EU funds in the period 2014-2020. The strategy should identify future development trends for ŁAM so as to enable enhancement of the competitiveness and economic potential of the area as a whole as well as the administrative divisions that comprise it.

The project consists of establishing a diagnosis and elaborating, on this basis, a development strategy and a plan of concrete actions supporting the development of the metropolitan area. The strategy should lead to identification of common goals for all local government entities constituting ŁAM and

\footnotetext{
9 Łódź applied in February 2013 for a subsidy toward the preparation of the 'Strategy' in the framework of the Operational Programme Technical Assistance providing support to local governments in planning functional urban areas. The subsidy was granted in April 2013. Overall value of the project is 3 million, of which 2.7 million is the subsidy from EU funds.
} 
stimulate links between them, thus increasing its competitiveness. For selected activities set out in the strategy, technical documentation should be prepared. All these measures should enable a better utilisation of the funding in the next EU programming period and create a solid foundation for implementation of Integrated Territorial Investments.

Despite the planning initiatives mentioned above, for many years there were no significant institutional level proposals for a formal agreement to create "Łódź metropolitan association", which differentiates Łódź unfavourably from other metropolitan centres in Poland. The taking of action aimed at seeking strategic solutions for Łódź metropolitan area and obtaining external funds for working out such solutions has resulted for the first time in concrete steps towards institutionalisation of cooperation within $Ł A M{ }^{10}$

Another attempt at institutionalisation of such cooperation was made in December 2012, with the aim of creating a framework for utilising EU funds for 2014-2020. Its effect was the signing of a letter of intent by 31 representatives of local government entities representing the city of Łódź, municipalities and districts making up the metropolitan area, the Marshal of Łódź voivodeship and the Voivode of Łódź.11

The next step was the establishment on 15 April 2014 of the Łódź Metropolitan Area Association $^{12}$ by 27 municipalities, which was

10 Before that the municipalities that make up the metropolitan area entered only into very limited (in spatial and factual terms) inter-municipality agreements intended to solve problems concerning local transport, water supply and sewerage, waste management, education, health care and welfare services.

11 A survey of municipalities found that potential benefits from creating a metropolitan area as perceived by the respondents were: (a) better position for obtaining funds for municipal investments, (b) expansion of infrastructural systems, (c) inflow of external investment capital, (d) starting/strengthening cooperation with other municipalities, (e) increasing innovativeness of local economy and $(f)$ increasing the number of business entities.

12 The aims of the Association are: (a) supporting the idea of local self-government and protecting common interests of the members of the Association, (b) promoting cooperation and integration of $Ł M A^{\prime} s$ local the intended outcome of the process of building metropolitan cooperation in the organisational dimension. An important stimulus for this step was seeking an effective way to obtain EU funding. Integrated territorial investments being part of metropolitan cooperation will enable expenditure of 217 million euros. The Association is expected to contribute to the integration of local governments' activities, improvement of the technical and social infrastructure, and enhancement of territorial cohesion and the role of $七 A M$ at the national and international scale.

The undertaking of the project Łódź Metropolitan Area Development Strategy was possible thanks to the inter-municipality cooperation initiated in 2012. The result of the first phase of the project was preparation of the Strategic Diagnosis of Łódź Metropolitan Area at the beginning of 2014. The second phase of the project, involving formulation of the strategy of development and integrated territorial investments, was completed in mid2014. In July the Strategy (Strategia ... 2014) was approved by the Steering Committee of the Łódź Metropolitan Area Development Strategy Project and the Board of the Łódź Metropolitan Area Association. ${ }^{13}$

The chief message of the Łódź Metropolitan Area Development Strategy is the need for comprehensive, i.e. territorial, thematic and inter-partner integration of actions promoting the development of the entire area, with:

- territorial integration meaning that development activities should be conducted in compact areas in need of support and should generate supra-local effects;

- thematic integration meaning that development activities should be joined into thematic groups and should result in enhanced

governments, (c) promoting partnership in cooperation, (d) supporting socio-economic development of $Ł M A$, (e) working towards common policy of the associated communes, ( $f$ ) increasing the influence of $Ł M A$ on the implementation of actions within its area as part of the policy of supporting cohesion.

13 The document was subsequently passed for consultation to the Managing Institution of Łódź Voivodeship's RPO 2014-2020 (Marshal's Office) and for opinion to the Ministry of Infrastructure and Development. 
Table 2. Strategic goals and priorities of the Łódź Metropolitan Area Development Strategy and the Integrated Territorial Investments Strategy (the priorities that can be realised, fully or partially, under ITI Strategy are marked in grey)

\begin{tabular}{|c|c|}
\hline Strategic goals of $Ł M A$ development & $Ł M A$ development priorities \\
\hline $\begin{array}{l}\text { 1. Revitalisation of degraded areas } \\
\text { to create safe and attractive pub- } \\
\text { lic spaces that stimulate social } \\
\text { and economic activity }\end{array}$ & $\begin{array}{l}\text { 1.1. Integrated revitalisation in the spatial, natural, social, economic and } \\
\text { cultural dimensions } \\
\text { 1.2. Promoting business and economic activation in areas being revital- } \\
\text { ised } \\
\text { 1.3. Development of socially beneficial functions in areas being revital- } \\
\text { ised } \\
\text { 1.4. Promoting effective use of cultural heritage potential }\end{array}$ \\
\hline $\begin{array}{l}\text { 2. Creation of an integrated and } \\
\text { sustainable metropolitan trans- } \\
\text { port system }\end{array}$ & $\begin{array}{l}\text { 2.1. Integration, modernisation and development of metropolitan public } \\
\text { transport network } \\
\text { 2.2. Modernisation and expansion of road infrastructure }\end{array}$ \\
\hline $\begin{array}{l}\text { 3. Development of resource-saving, } \\
\text { low-emission economy and pro- } \\
\text { tection of natural environment }\end{array}$ & $\begin{array}{l}\text { 3.1. Improvement of energy efficiency and greater use of renewable } \\
\text { sources of energy } \\
\text { 3.2. Integration of actions aimed at development of municipal infrastruc- } \\
\text { ture and introduction of organizational and technological innova- } \\
\text { tions in environment protection } \\
\text { 3.3. Promoting effective use of natural resources }\end{array}$ \\
\hline $\begin{array}{l}\text { 4. Development of human and } \\
\text { social capital and information- } \\
\text { based, civil society }\end{array}$ & $\begin{array}{l}\text { 4.1. Supporting employment, occupational mobility and business activity } \\
\text { 4.2. Supporting community activation and poverty elimination } \\
\text { 4.3. Improving the standards and accessibility of education and health } \\
\text { care services as well as public e-services } \\
\text { 4.4. Improvement of employability through adjustment of education } \\
\text { to the needs of economy }\end{array}$ \\
\hline $\begin{array}{l}\text { 5. Strengthening the metropolitan } \\
\text { functions and cohesion of } Ł M A\end{array}$ & $\begin{array}{l}\text { 5.1. Integration and coordination of public policies aimed at more effec- } \\
\text { tive realisation of tasks and projects } \\
\text { 5.2. Transfer and commercialisation of knowledge for modern, competi- } \\
\text { tive economy and society } \\
\text { 5.3. Building and protecting the identity of } Ł M A \text { and creating its image } \\
\text { based on consistent cultural heritage } \\
\text { 5.4. Increasing internal and external attractiveness of } Ł M A \text { through } \\
\text { territorial marketing }\end{array}$ \\
\hline
\end{tabular}

Source: Strategia ... (2014: 29).

integrity of the area in social, economic, environmental and cultural spheres;

- inter-partner integration meaning that development activities should be undertaken in the form of cooperation between various partners: local government entities, business entities and the public sector.

The Strategy sets out five equally important strategic goals, with only a few priorities relating to the first four goals that are to be realised under the Integrated Territorial Investments Strategy (see Tab. 2).

In the framework of common strategy adopted by $Ł M A$ local government entities, over 70 investment projects worth about 1.2 billion zlotys (including 800 million zlotys in EU subsidies) are planned. The investments, approved by the Łódź Metropolitan Area Association, mostly include undertakings involving revitalisation, thermo-modernisation (mainly educational establishments), and modernisation of cultural infrastructure and transport systems. About 460 million zlotys (including nearly 300 million zlotys from the EU) is to be assigned for revitalisation projects, such as revitalisation and modernisation of places of historical interest as well as old residential quarters in the centre of Łódź. 300 million zlotys (including 200 million EU funds) has been allocated for thermo-modernisation (28 projects), and 108 million zlotys (including about 91 million EU subsidies) - for cultural 
infrastructure development (7 projects). Other projects include reconstruction of roads, purchase of means of transport, Łódź Metropolitan Tramway, modernisation of the heating system in Łódź and selected ŁMA cities.

\section{Future development - challenges, opportunities and barriers}

Łódź Metropolitan area - a space having a complex socio-economic structure - has a monocentric character, with strong domination of the central city. Assessment of this area's potential makes it possible to identify the strengths and weaknesses that condition its development.

Among the barriers, the question of trust, which is often underestimated, is of primary importance, especially in view of the recent reinstatement of local government at municipality level. Łódź is the strongest actor in the metropolitan area governance system, and the limited trust for the metropolitan city authorities on the part of the adjacent urban and rural municipalities as well as the lack of inter-municipality cooperation was often visible when attempts were made to solve important problems common for the entire region. This lack of trust is confirmed by a survey of local governments within $Ł M A$, which found that loss of powers to the central city was believed to be the main threat resulting from integration at metropolitan area level. ${ }^{14}$ The increasing inter-municipality cooperation that has recently been observed, with Łódź being one of the partners, seems to indicate that this long-lasting barrier is finally being overcome. ${ }^{15}$

Spatial planning at the level of local government entities comprising $Ł M A$ is another problem area. Spatial policy objectives set out in studies of determinants and directions of spatial development, prepared and updated by each of the municipalities, are more or less up to date, but in respect of local plans of spatial

\footnotetext{
14 The next biggest threat as indicated by the municipalities that were surveyed was greater complexity of legal regulations and procedures.

15 For more on inter-municipality cooperation see Kozłowski \& Marszał 2010a and Kozłowski \& Marszał 2010b: 127-129.
}

development the situation varies widely among the municipalities - in some of them the percentage of area covered by such plans is very low (see Fig. 3). In addition, local plans for areas which belong to adjoining municipalities often lack consistency.

The absence of coordination of planning processes and the lack consistency between spatial policies of local government entities result in spatial conflicts in border areas of neighbouring municipalities, ${ }^{16}$ which is a serious threat to creating cohesion within the metropolitan area..$^{17}$ It is a situation which needs to be changed urgently (Bald 2005: 156).

The lack of effective supra-local planning and coordination, leading, among others, to allocating large areas of land for such functions as logistics, warehousing, non-agricultural production and housing, ${ }^{18}$ results in uncontrolled spreading of urbanised areas (including new housing developments), which creates spatial chaos and causes degradation of the natural environment and cultural landscape of ŁMA (Strategia ... 2013: 49). It also collides with the spatial policy of the central city, aiming to contain the process of urban sprawl (Bald 2005: 158).

Another challenge to the development of $Ł M A$ in the following decades is unfavourable (in comparison with the country as a whole and with other regions) demographic situation and progressing depopulation processes. A population decrease of $14.9 \%$ is forecast to take place by 2029 - from 1,160 thousand to 987 thousand (decrease of 173 thousand).

\footnotetext{
16 According to research conducted by Ułańska and Borowska-Stefańska (2011), the existing and potential spatial and functional conflicts in ŁMA occur along 45 kilometres of inter-municipality boundaries (14\% of the length of all the boundaries studied), mainly in places where residential development adjoins forests or open spaces in areas covered or to be covered by legal protection (for more see Ulańska \& BorowskaStefańska 2012: 38-39 and other). Conflicts in ŁMA's ecological networks are addressed in Pielesiak (2012a).

17 A synthetic assessment of $Ł M A$ cohesion can be found in Bartosiewicz (2012b) and Bartosiewicz \& Pielesiak (2011).

18 Large and compact areas for residential development dominate mainly in municipalities bordering Łódź and in all larger cities of $Ł M A$.
} 


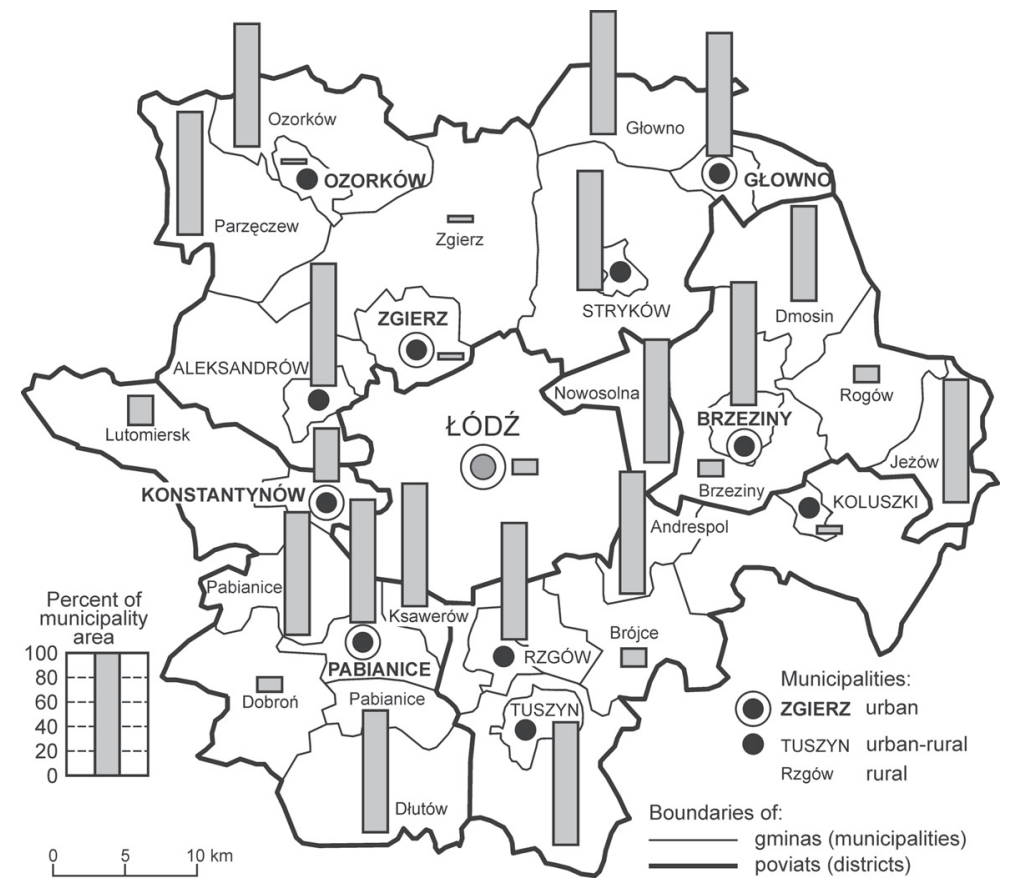

Figure 3. Percentage of areas with local spatial development plans in ŁMA municipalities in 2012 Source: based on data from Łódź Voivodeship Spatial Planning Office.

Łódź is predicted to have the greatest decrease (19\%), which is mainly due to natural decrease of population. In the districts surrounding the central city migrations will play an important role, affecting most negatively the population size of the Brzeziny district (Jaeschke \& Obraniak 2005: 74-75). Łódź Metropolitan Area will experience a drastic decline in the number of pre-productive age persons, a smaller decrease of the productive age population, and a significant increase in the number of retired persons. Apart from Upper Silesia Metropolitan Area, Łódź has the most unfavourable demographic indicators: $20 \%$ of post-productive age population, 175 post-productive age persons/100 pre-productive age persons, natural population decrease, and only minimally positive migration balance.

A factor significant for future development of Łódź and the surrounding area is recognition of this region in official documents concerning Poland's spatial policy as one of the country's key nodes playing a major part in promoting the competitiveness of Polish economy at the international scale.

Central location of $Ł M A$ and its position in Poland's transport and settlement network is a key element conditioning future development of this region. Opportunities for growth are connected with proximity to the intersection of A1/A2 motorways and S8/S14 highways and the resulting locational economies within transport infrastructure corridors connecting major European growth poles. Additional positive factors include the planned high-speed railway and Łódź Władysław Reymont Airport, although the airport has now a secondary position on the map of passenger and cargo transport..$^{19}$ Much more important

19 The number of transport and logistics companies cooperating with the airport is growing; The airlines using freight services of the Łódź Airport include Lufthansa Cargo, SAS Cargo, Air France, KLM, Martinair, Alitalia, Emirates SKY, and the transport companies are: DB Schenker, Panalpina, Omega Air, Air Logistics, Express Polska, Polsped, Raben, DHL GF. 
for strengthening the metropolitan status of Łódź would be construction of an international airport between Łódź and Warsaw (near Skierniewice/Rawa Mazowiecka). The existing and planned elements of infrastructure, enabling quick and easy transport, would give $Ł M A$ the status of a European integrated transport node, in addition to its leading position in Poland as a logistics centre. ${ }^{20}$

The relatively small size of $Ł M A$ (compared to other metropolitan areas in Poland) can be regarded as its strength - the time needed to get to the central city from the most distant locations does not take more than 60 minutes, which facilitates spatial integration processes and functional links, as well as analysis and coordination of actions.

However, Łódź Metropolitan Area lacks cohesion. Some of the outlying municipalities are only loosely tied with the central city and do not perform any major functions substitutive or complementary for the metropolis. The municipalities in close proximity to Łódź are developing more quickly than those located peripherally. Internal disparities within ŁMA also exist in infrastructure and the resulting infrastructural links, weak especially in the case of a few peripheral municipalities, which does not favour spatial deconcentration of metropolitan functions, characteristic of strongly developed metropolitan areas (Marszał \& Pielesiak 2008: 195). Weak cohesion is also due to bad technical condition of some of the provincial and district roads and lack of ring roads in many ŁMA cities. It is also necessary to modernise the railway network and adjust it to the needs of metropolitan public transport, and achieve integration of the mass transport system, which requires cooperation of all local government levels in ŁMA and rail carriers. ${ }^{21}$

Among the strengths of Łódź Metropolitan Area is its multi-ethnic cultural heritage, common history and 19th century post-industrial

\footnotetext{
${ }^{20}$ An additional asset of $Ł M A$ is a relatively low level of traffic congestion (compared with other metropolitan centres), both in Łódź and the surrounding region.

21 For more on transport cohesion see Bartosiewicz \& Pielesiak (2012).
}

heritage, which creates opportunities not only for development of so-called sentimental tourism, but also for building new social and economic relations and undertaking cultural initiatives promoting international cooperation and inflow of capital. ${ }^{22}$ The legacy of the multicultural development of Łódź and nearby towns and of the 19th century textile industry is visible in the spatial structure of urban fabric and unique factory-residential complexes. Because of many years of neglect, post-industrial areas including housing have suffered serious degradation. Comprehensive revitalisation of these spaces is now a major challenge. There are many examples of successful transformation of old post-industrial urban fabric into attractive, easily accessible space fulfilling commercial, service and entertainment functions characteristic of metropolitan cities and favourable, among others, to strengthening the cultural identity of the city and to developing international contacts. ${ }^{23}$

Łódź enjoys a strong position as centre of academic and research activity, and $Ł M A$ has a significant concentration of highly qualified and well-educated labour force (Łódź has over 90 thousand students). On the other hand, however, there is a negative process competition from other metropolitan centres results in draining the labour market of Łódź.

The changes that are taking place in the economic structure of Łódź agglomeration in the last two decades and its transformation towards a knowledge-based economy are positive processes. The attractiveness of Łódź agglomeration for investors is largely connected with the functioning of Łódź Special Economic Zone, in which many high-tech firms are located, thus raising the competitiveness of $Ł M A$. The inflow of foreign capital as well

\footnotetext{
22 Behavioural factors of business activity location justify this diagnosis.

23 These are investments of supra-regional importance changing the appearance of Łódź, such as commercial and service centres (e.g. 'Manufactura' in a post-factory complex, construction of the New Centre of Łódź and reconstruction of the railway system, or successful revitalisation of a number of post-industrial complexes, e.g. Księży Młyn or lofts at Scheibler's factory).
} 
as activation of domestic entrepreneurship prompts innovativeness and technological progress (cf. Stawasz 2008: 201). ${ }^{24}$ Despite these positive trends, ŁMA is still characterized by a relatively low concentration of capital and control functions of international corporations, as well as disintegration of the creative sector and a low presence of the 4th sector in the economy. ${ }^{25}$

Important for long-term development prospects of $Ł M A$ is its position in Poland's settlement and economic system, and particularly its relations with Warsaw Metropolitan Area and the possibility of formation of WarsawŁódź metropolis, based, among others, on the emergence of a zone of strong interpenetration of both cities' spheres of influence. Polycentric metropolitan systems have stronger polarisation capacity and more favourable conditions for metropolitan functions development, and the zone of overlapping influences of metropolitan centres offers special locational economies to business enterprises. Polycentric systems not only foster socio-economic development of the country, but also, by enabling better utilisation of resources and consolidation of efforts, contribute to higher growth rates of the cooperating agglomerations.

An essential condition for development of a bipolar system is adequate 'gravitational potential' of the neighbouring centres which depends on the distance between them and their demographic and economic potential. It is not the only necessary condition - equally important is a high degree of complementarity of socio-economic structures of the cooperating metropolitan cities, as well as willingness and ability to coordinate their policies. In the case of Warsaw and Łódź, the first two conditions are fulfilled, so development of a bipolar system depends on the fulfilment of the third condition (Marszał et al. 2013).

24 Łódź has the fifth place in Poland as measured by the number of foreign investors (2004). There are 54 firms with foreign capital, which places Łódź before Warsaw, Poznań, Wrocław or Kraków (Sokołowicz 2007).

25 Proportion of 4th sector entities in the total number of businesses in Łódź is 35\% and is lower than in other Polish metropolises (except Szczecin)
In the light of Koncepcja Przestrzennego Zagospodarowania Kraju (2012) (Conception of Spatial Development of the Country), Warsaw and Łódź (besides Gdańsk-GdyniaSopot, Kraków and Katowice, and Bydgoszcz and Toruń) are viewed as a bi-polar system (duopolis) which requires actions strengthening the functional ties. This is a good starting point for initiating all sorts of joint activities and for seeking support and funding for investments intended to intensify cooperation. These indications, however, are not reflected in lower-level (voivodeship, local) documents.

The Warsaw-Łódź duopolis could become a European keystone both organizing Polish space (in economic and cultural terms) and constituting a bridge between Western Europe and the East of the continent. The strategic goal of duopolitan cooperation should be generation of accelerated growth of both cities and the surrounding metropolitan area, as well as rational space management and coordination of spatial policy in areas of overlapping influences. To achieve these goals and benefits, it is necessary to forego short-term, local, particularistic interests in favour of the long-term vision of Łódź-Warsaw cooperation, on a partnership basis, in the framework of an integrated metropolitan area.

\section{Final remarks}

Łódź Metropolitan Area certainly has considerable growth potential, but to help it develop, it is necessary to take full advantage of the area's location in European space, availability of EU funds, cultural heritage and social capital. A major challenge is coordination of actions of local government entities forming $Ł M A$ so as to conform to a consistent conception of metropolitan area development (Karski 2005: 107). The chance to achieve this has been created by Łódź Metropolitan Area Association and Development Strategy - regardless of the opinion on its quality, it is the first agreed document initiating coordinated actions aimed at building the cohesion and competitiveness of the entire area. Łódź Metropolitan Area, despite a number of barriers, 
has potential to become a modern, creative node of culture, science and innovative economy and a major link in the European settlement system. As a result of socio-economic transformations during the past few decades, Łódź and the surrounding region, which for a century and a half had depended on the textile industry, has overcome the deep crisis of the 1990s and has entered a new era

\section{References}

ANTIKAINEN J., 2005. The concept of Functional Urban Area. Findings of the ESPON project 1.1.1. Informationen zur Raumentwicklung, Heft 7, pp. 447-454.

BALD K., 2005. Wybrane zagadnienia planowania Łódzkiego Obszaru Metropolitalnego [in:] K. Bald, T. Markowski (eds.), Obszar Metropolitalny Łodzi - wyzwania i problemy, Biuletyn KPZK PAN, 215, Warszawa: Komitet Przestrzennego Zagospodarowania Kraju PAN, pp. 150-168.

Bald K., Markowski T. (eds), 2005. Obszar Metropolitalny Łodzi - wyzwania i problemy. Biuletyn KPZK PAN, 215, Warszawa: Komitet Przestrzennego Zagospodarowania Kraju PAN.

Bartosiewicz B., 2012a. Powiqzania społeczne w Łódzkim Obszarze Metropolitalnym [in:] B. Bartosiewicz, T. Marszał, I. Pielesiak (eds.), Spójność terytorialna Łódzkiego Obszaru Metropolitalnego, Studia KPZK PAN, vol. 147, Warszawa: Komitet Przestrzennego Zagospodarowania Kraju PAN, pp. 83-104.

BARTOSIEWICZ. B., 2012b. Spójność terytorialna Łódzkiego Obszaru Metropolitalnego - pomiar zjawiska [in:] B. Bartosiewicz, T. Marszał, I. Pielesiak (eds.), Spójność terytorialna Łódzkiego Obszaru Metropolitalnego, Studia KPZK PAN, vol. 147, Warszawa: Komitet Przestrzennego Zagospodarowania Kraju PAN, pp.155-168.

Bartosiewicz B., Marszat T., Pielesiak I. (eds.), 2012. Spójność terytorialna Łódzkiego Obszaru Metropolitalnego. Studia KPZK PAN, vol. 147, Warszawa: Komitet Przestrzennego Zagospodarowania Kraju PAN.

Bartosiewicz B. Pielesiak I., 2010. Spójność obszaru metropolitalnego - koncepcja badawcza [in:] S. Liszewski (ed.), Obszary metropolitalne of building a modern, competitive, knowledgebased economy and metropolitan functions development.

Editors' note:

Unless otherwise stated, the sources of tables and figures are the authors', on the basis of their own research. we współczesnym środowisku geograficznym, Łódź: Nowa Era, pp. 69-77.

Bartosiewicz B., Pielesiak I., 2011. How to measure territorial cohesion of a metropolitan area - proposal of a research concept [in:] T. Marszał (ed.), Urban regions as engines of development, Studia Regionalia KPZK PAN, vol. 31, Warszawa: Komitet Przestrzennego Zagospodarowania Kraju PAN, pp. 65-75.

Bartosiewicz. B., Pielesiak I., 2012. Powiqzania transportowe w Łódzkim Obszarze Metropolitalnym [in:] B. Bartosiewicz, T. Marszał, I. Pielesiak (eds), Spójność terytorialna Łódzkiego Obszaru Metropolitalnego, Studia KPZK PAN, vol. 147, Warszawa: Komitet Przestrzennego Zagospodarowania Kraju PAN, pp. 105-138.

BERRY B.J.L., 1967. Functional economic areas and consolidated urban regions of the US. New York: Social Sciences Research Council.

BerRy B.J.L., GILlard Q., 1977. The changing shape of metropolitan America, 1960-1970: Commuting patterns, urban fields and decentralization process. Cambridge: Ballinger Publishing Company.

BrezZI M., VeneRI P., 2014. Assessing polycentric urban systems in the OECD: Country, regional and metropolitan perspectives. OECD Regional Development Working Papers, Paris: OECD.

BUDZYNOWSKA O., 2000. Obszary metropolitalne, ich struktura i funkcje w układach terytorialnych. Samorząd Terytorialny, no. 10, pp. 37-45.

CAstells M., 2002. Local and global: Cities in the network society. Journal of Economic and Social Geography, vol. 93, no. 5, pp. 548-558.

CheshiRe P., Hay D., 1989. Urban problems in Western Europe: An economic analysis. London: Unwin Hyman. 
Czrż T., 2009. Koncepcja aglomeracji miejskiej i obszaru metropolitalnego w polskiej geografii miast [in:] W. Maik (ed.), Aglomeracje miejskie w Polsce na przełomie XX i XXI wieku. Problemy rozwoju, przekształceń strukturalnych i funkcjonowania, Bydgoszcz: Wydawnictwo Uczelniane Wyższej Szkoły Gospodarki, pp. 15-30.

Diagnoza strategiczna Łódzkiego Obszaru Metropolitalnego, Łódź: Polskie Towarzystwo Ekonomiczne. Oddział w Łodzi, styczeń 2014 [typescript].

DICKINSON R.E., 1934. Metropolitan regions in the United States, Geographical Review, no. 23, pp. 278-286.

Dijkstra L., Poelman H., 2012. European cities the EU-OECD functional urban area definition. Redefining 'urban': A new way to measure metropolitan areas. OECD Publishing.

DOMAŃSKI B., 2008. Rozwój polskich metropolii a regiony peryferyjne. Bezpowrotna separacja czy współzależność rozwoju [in:] T. Marszał (ed.), Rola polskich aglomeracji wobec wyzwań strategii lizbońskiej, Studia KPZK, vol. 120, Warszawa: Komitet Przestrzennego Zagospodarowania Kraju PAN, pp. 135-143.

DZIEWOŃSKI K., 1973. W sprawie podstawowych pojęć $i$ terminów używanych $w$ analizie i planowaniu wielkich aglomeracji miejskich. Biuletyn KPZK PAN, 79, Warszawa: Komitet Przestrzennego Zagospodarowania Kraju PAN.

DZIEWOŃSKI K., 1975. The place of urban agglomerations in the settlement system of Poland. Geographia Polonica, no. 30, pp. 9-20.

Eberhardt P., 2002. Studia nad problematyka delimitacji aglomeracji miejskich w Polsce [in:] G. Węcławowicz (ed.), Warszawa jako przedmiot badań w geografii społeczno-ekonomicznej, Prace Geograficzne, 184, Warszawa: Instytut Geografii i Przestrzennego Zagospodarowania PAN, pp. 55-64.

FelTYNOWSKI M., 2009. Łódzki Tramwaj Regionalny jako przykład projektu z zakresu zintegrowanego transportu w obszarze metropolitalnym [in:] M.E. Sokołowiecz (ed.), Miasta i regiony wobec współczesnych wyzwań, Łódź: Wydawnictwo Biblioteka, pp. 157-164.

Friedman J., Miller J., 1965. The urban field. Journal of America Institute of Planners, vol. 31, no. 4, pp. 312-320.
GonTARSKI Z., 1972. Delimitacja obszarów metropolitalnych w Polsce. Statystyka Terenowa, no. 8, Warszawa: GUS.

GonTARSKI Z., 1980. Obszary metropolitalne w Polsce. Biuletyn KPZK PAN, 109, Warszawa: Komitet Przestrzennego Zagospodarowania Kraju PAN.

Hall P., HaY D., 1980. Growth centers in the European urban system. London: Heinemann Educational Books.

Hay D., Hall P., 1977. Urban regionalization of Great Britain: 1971. European Urban Systems Working paper 1.1., IASA, Reading: Department of Geography of the University of Reading.

IWANICKA-LYRA E., 1969. Delimitacja aglomeracji wielkomiejskich w Polsce. Prace Geograficzne, 76, Warszawa: Instytut Geografii i Przestrzennego Zagospodarowania PAN.

Jaeschike A., Obraniak W., 2005. Perspektywy demograficzne Łódzkiego Obszaru Metropolitalnego [in:] K. Bald, T. Markowski (eds), Obszar Metropolitalny Łodzi - wyzwania i problemy, Biuletyn KPZK PAN, 15, Warszawa: Komitet Przestrzennego Zagospodarowania Kraju PAN, pp. 73-92.

JAKÓBCZYK-GRYSZKIEWICZ J., 2011. Ewolucja procesów suburbanizacji w regionie miejskim Łodzi [in:] J. Jakóbczyk-Gryszkiewicz (ed.), Regiony miejskie w Polsce. Dwadzieścia lat transformacji, Łódź: Wydawnictwo Uniwersytetu Łódzkiego, pp. 89-116.

JakóbCZYK-GRYSZKIEWICZ J., MARCińCZAK SZ., SIEJKOWSKA A., 2010. Dynamika i skutki procesów urbanizacji w regionach miejskich po 1990 roku na przykładzie regionu miejskiego Łodzi. Łódź: Wydawnictwo Uniwersytetu Łódzkiego.

JeWtuchowicz A., Wóscik M. (eds.), 2010. Łódzka metropolia: Problemy integracji gospodarczej. Łódź: Wydawnictwo Biblioteka.

KaczMarek T., MikUta Ł., 2007. Ustroje terytorialno-administracyjne obszarów metropolitalnych w Europie. Poznań: Bogucki Wydawnictwo Naukowe.

KARSKI K., 2005. Uwarunkowania rozwoju obszaru metropolitalnego [in:] K. Bald, T. Markowski (eds.), Obszar Metropolitalny Łodzi - wyzwania i problemy, Biuletyn KPZK PAN, 15, Warszawa: Komitet Przestrzennego Zagospodarowania Kraju PAN. pp. 93-108.

KLIMCZYK M., MIJAKowski A., 1968. Próba delimitacji regionów metropolitalnych $w$ Polsce. Wiadomości Statystyczne GUS, 3, pp. 27-30. 
Korcelli P., 1976. Aglomeracje miejskie w systemach osadniczych. Przegląd Geograficzny, vol. 4, no. 48 , pp. 589-598.

KorCelli P., 1981. Regiony miejskie w systemie osadniczym Polski [in:] K. Dziewoński, P. Korcelli (eds.), Studia nad migracjami i przemianami systemu osadniczego w Polsce, Prace Geograficzne, 140, Warszawa: Instytut Geografii i Przestrzennego Zagospodarowania PAN, pp. 189-212.

Korcelli-Olejniczak E., 2012. Region metropolitalny - pojęcie, struktura przestrzenna, dynamika. Prace Geograficzne, 235, Warszawa: Instytut Geografii i Przestrzennego Zagospodarowania PAN.

KozŁoWsKI S.J., MarsZAŁ T., 2010a. Metropolitan areas in Poland - context of territorial cohesion and co-operation between communes [in:] M. Habrel, T. Marszał (eds.), Urban management and territorial organisation. The case of Polish and Ukrainian big cities at the beginning of 21st century, Łódź: Łódź University Press, pp. 79-88.

Kozłowski S.J., Marszat T., 2010b. Obszary metropolitalne w Polsce - kontekst spójności terytorialnej i współpracy międzygminnej. Biblioteka Wiadomości Statystycznych, vol. 63, pp. 127-129.

Kunc J., Tonev P., Szczyrba Z., Frantal B., 2012. Commuting for retail shopping as a part of the daily urban systems (Brno, the Czech Republic). Geographia Technica, no. 1, pp. 36-45.

LIER K., 1965. Region metropolitalny Warszawy. Próba delimitacji. Biuletyn KPZK PAN, 35, Warszawa: Komitet Przestrzennego Zagospodarowania Kraju PAN, pp. 50-87.

LIsZEWSKI S., 1999. Ewolucja funkcji regionotwórczych Łodzi [in:] A. Suliborski (ed.), Zasięg regionu łódzkiego w świetle badań społecznych preferencji administracyjnej i powiqzań społeczno-gospodarczych, Acta Universitatis Lodziensis. Folia Geographica Socio-oeconomica, Łódź: Wydawnictwo Uniwersytetu Łódzkiego, pp. 41-59.

LISzEWski S., 2005. Delimitacja Łódzkiego Obszaru Metropolitalnego [in:] K. Bald, T. Markowski (eds), Obszar Metropolitalny Łodzi - wyzwania i problemy, Biuletyn KPZK PAN, 15, Warszawa: Komitet Przestrzennego Zagospodarowania Kraju PAN, pp. 25-47.

Liszewski S., Szafrańska E., Wolaniuk A, 2008. Szkolnictwo wyższe Łodzi i jego rola w funkcji metropolitalnej miasta. Łódź: Łódzkie Towarzystwo Naukowe.
MANTLEY E., 2014. Identifying functional urban regions within traffic flow. Regional Studies, vol. 1, no. 1, pp. 40-42.

MCKENZIE R.D., 1933. The metropolitan community. New York: Mc Grow-Hill.

Markowski T., 2005. Procesy integracji i dezintegracji obszarów zurbanizowanych - wyzwania dla polityki metropolitalnej [in:] P. Lorens (ed.), Integracja i dezintegracja obszarów metropolitalnych, Warszawa: Urbanista, pp. 10-20.

Markowski T., Marszat T., 2005. Funkcje i zarzadzanie obszarami metropolitalnymi. Samorząd Terytorialny, 7-8, pp. 7-16.

Markowski T., Marszat T., 2006a. Metropolie, obszary metropolitalne, metropolizacja - Problemy i pojęcia podstawowe. Warszawa: Komitet Przestrzennego Zagospodarowania Kraju PAN.

Markowski T., Marszat T., 2006b. Metropolitan area - functions and management (perspectives of the Polish spatial planning system) [in:] T. Markowski, M. Turała, New members - new challenges for the European Regional Development Policy, Studia Regionalia, 18, Warszawa: Commitee for Space Economy and Regional Planning, Polish Academy of Sciences, pp. 239-249.

Markowski T., Marszat T., 2007. Metropolie i procesy metropolizacji w Polsce [in:] Z. Makieła, R. Fedan (eds.), Procesy metropolizacji w regionie podkarpackim Rzeszów-Lwów, Biuletyn KPZK, 230, Warszawa: Komitet Przestrzennego Zagospodarowania Kraju PAN, pp. 8-26.

MARSZAL T., 2004. Some remarks on metropolitan development - the case of the City of Lodz [in:] T. Gök, T. Marszał (eds.), Urban and regional development. Concepts and experiences, Studia Regionalia, 14, Warszawa: Commitee for Space Economy and Regional Planning, Polish Academy of Sciences, pp. 129-136.

MARSZAt T., 2005a. Funkcje obszaru metropolitalnego Łodzi [in:] K. Bald (ed.), Obszar Metropolitalny Łodzi - wyzwania i problemy, Biuletyn KPZK PAN, 215, Warszawa: Komitet Przestrzennego Zagospodarowania Kraju PAN, pp. 48-27.

MARSZAŁ T., 2005b. Struktura funkcji gospodarczych w Łódzkim Obszarze Metropolitalnym [in:] T. Marszał (ed.) Gospodarka w przestrzeni polskich miasta, Biuletyn KPZK PAN, 216, Warszawa: Komitet Przestrzennego Zagospodarowania Kraju PAN, pp. 200-211.

Marszat T., Bartosiewicz B., Lamprecht M., PieleSIAK I., 2013. Uwarunkowania i kierunki rozwoju 
współpracy duopolitalnej Warszawa - Łódź. Expert report prepared for the city of Łódź Office [typescript].

Marszat T., Pielesiak I., 2008. Spójność obszaru metropolitalnego w świetle powiqzań infrastrukturalnych (przykład Łódzkiego Obszaru Metropolitalnego) [in:] T. Marszał, (ed.), Rola polskich aglomeracji wobec wyzwań Strategii Lizbońskiej, Studia KPZK PAN, vol. 120, Warszawa: Komitet Przestrzennego Zagospodarowania Kraju PAN, pp. 180-196.

OgrodowczYk A., 2012. Struktura społeczno-gospodarcza w Łódzkim Obszarze Metropolitalnym [in:] B. Bartosiewicz, T. Marszał, I. Pielesiak (eds.), Spójność terytorialna Łódzkiego Obszaru Metropolitalnego, Studia KPZK PAN, vol. 147, Warszawa: Komitet Przestrzennego Zagospodarowania Kraju PAN, pp. 45-82.

PIELESIAK I., 2007. Metropolitan areas in Poland (the chosen aspects) [in:] T. Marszał, W. Zmitrowicz (eds.), Metropolises and metropolitan areas - Structures, functions and role: (based on Polish and Brazilian experience), Studia Regionalia, vol. 20, Warszawa: Committee for Spatial Economy and Regional Planning Polish Academy of Sciences, pp. 33-46.

PIELESIAK I., 2012. Powiqzania ekologiczne Łódzkiego Obszaru Metropolitalnego [in:] B. Bartosiewicz, T. Marszał, I. Pielesiak (eds.), Spójność terytorialna Łódzkiego Obszaru Metropolitalnego, Studia KPZK PAN, vol. 147, Warszawa, pp. 139-154.

PIelesIAK I., 2012, Delimitacja i instytucjonalizacja Łódzkiego Obszaru Metropolitalnego [in:] B. Bartosiewicz, T. Marszał, I. Pielesiak, (eds.), Spójność terytorialna Łódzkiego Obszaru Metropolitalnego, Studia KPZK PAN, vol. 147, Warszawa: Komitet Przestrzennego Zagospodarowania Kraju PAN, pp. 169-186.

Plan Zagospodarowania PRZESTRZENNEGo WOJEWÓDZTWA ŁÓDZKIEGO - AKTUALIZACJA, 2010. Act no. $L X / 1648 / 10$ of the Regional Parlament of the Łódź Voivodship as of 21 September 2010.

POTRYKOWSKA A., 1989. Funkcjonalne regiony miejskie w krajowym systemie osadniczym [in:] P. Korcelli, A. Gawryszewski (eds.), Współczesne przemiany regionalnych systemów osadniczych w Polsce. Prace Geograficzne, 152, Warszawa: Instytut Geografii i Przestrzennego Zagospodarowania PAN, pp. 55-75.

RakowsKa J., 2014. Codzienne dojazdy do pracy jako ekonomiczne kryterium rzadowych klasyfikacji i delimitacji obszarów (na przykładzie USA i Kanady). Studia Regionalne i Lokalne, no. 3(57), pp. 46-59.

ŚleszrŃŚSI P., 2013. Delimitacja Miejskich Obszarów Funkcjonalnych stolic województw. Przegląd Geograficzny, vol. 85, no. 2, pp. 173-197.

ŚLESZYŃSKI P., 2014. Delimitation and typology of functional urban regions in Poland based on commuting. Geographia Polonica, vol. 87, no. 2 , pp. 317-320.

ŚleszYŃSKI P., 2015. Problemy delimitacji miejskich obszarów funkcjonalnych w Polsce. Rozwój Regionalny i Polityka Regionalna, no. 29, pp. 37-53.

Śleszrński P., KomORnicki T., 2016. Klasyfikacja funkcjonalna gmin Polski na potrzeby monitoringu planowania przestrzennego. Przegląd Geograficzny, vol. 88, no. 4, pp. 469-488.

SMĘTKOWSKI M., 2007. Delimitacja obszarów metropolitalnych - nowe spojrzenie [in:] G. Gorzelak, A. Tucholska (eds.), Rozwój, region, przestrzeń, Warszawa: Ministerstwo Rozwoju Regionalnego, pp. 215-233.

SMĘTKOWSKI M., JaŁOWIECKI B., GORZELAK G., 2009. Obszary metropolitalne w Polsce: problemy rozwojowe i delimitacja. Raporty i Analizy EUROREG 1/2009, Warszawa: Centrum Europejskich Studiów Regionalnych i Lokalnych EUROREG.

SokoŁowicz M.E., 2007. Działalność przedsiębiorstw międzynarodowych a rozwój aglomeracji Łódzkiej [in:] A. Jewtuchowicz (ed.), Region w gospodarce opartej na wiedzy, Łódź: Wydawnictwo Uniwersytetu Łódzkiego.

STAWASz D., 2008. Ocena przekształceń gospodarki łódzkiej aglomeracji w kierunku budowania gospodarki opartej na wiedzy [in:] T. Marszał, (ed.) Rola polskich aglomeracji wobec wyzwań Strategii Lizbońskiej, Studia KPZK PAN, vol. 120, Warszawa: Komitet Przestrzennego Zagospodarowania Kraju PAN, pp. 197-205.

Strategia Rozwoju Województwa Łódzkiego do 2020r, 2013. Łódź: Urząd Marszałkowski Województwa Łódzkiego.

Strategia Rozwoju Łódzkiego Obszaru MetropollTALNEGO 2020+, 2014. Łódź: Polskie Towarzystwo Ekonomiczne Oddział w Łodzi.

Studium Rozwoju Łódzkiego Obszaru MetropoLITALnEgo, 2013. Łódź: Biuro Planowania Przestrzennego Województwa Łódzkiego.

Suliborski A., PrZYgodzki Z. (eds.), 2010. Łódzka metropolia. Problemy integracji społecznej 
i przestrzennej. Łódź: Katedra Gospodarki Regionalnej i Środowiska, Uniwersytet Łódzki.

SWIANIEWICZ P., KLIMSKA K., 2005. Społeczne i polityczne zróżnicowanie aglomeracji w Polsce waniliowe centrum, mozaika przedmieść. Prace i Studia Geograficzne, no. 35, pp. 45-70.

TARKOWSKI M., 2005. Dzienny system miejski jako metropolitalny obszar statystyczny - propozycja delimitacji [in:] T. Markowski (ed.), Planowanie i zarzadzanie w obszarach metropolitalnych, Biuletyn KPZK, no. 221, Warszawa: Komitet Przestrzennego Zagospodarowania Kraju PAN, pp. 95-104.

UtańSKA J., BOROWSKA-STEFAńSKA M., 2012. Użytkowanie ziemi i polityka przestrzenna $w$ Łódzkim Obszarze Metropolitalnym [in:] B. Bartosiewicz, T. Marszał, I. Pielesiak (eds.), Spójność terytorialna Łódzkiego Obszaru Metropolitalnego, Studia KPZK PAN, vol. 147, Warszawa: Komitet Przestrzennego Zagospodarowania Kraju PAN, pp. 13-44.

Wolaniuk A., 1997. Funkcje metropolitalne Łodzi i ich rola w organizacji przestrzennej. Łódź: Łódzkie Towarzystwo Naukowe.

VENERI P., 2010. Urban polycentricity and the costs of commuting: Evidence from Italian metropolitan areas. Growth and Change, vol. 41, no. 3, pp. 403-429.

ZBOROWSKI A., 2004. Podejście funkcjonalno-strukturalne $w$ badaniach delimitacji obszarów metropolitalnych w Polsce (przykład Krakowa) [in:] J. Słodczyk (ed.) Przemiany struktury przestrzennej miast w sferze funkcjonalnej i społecznej, Opole: Uniwersytet Opolski, pp. 25-39. 